\title{
THE ENDURANCE OF THE MODERNIST PLANNING PARADIGM: THE FUNCTIONAL CITY IN CONTEMPORARY PLANNING IN MEDELLÍN, COLOMBIA
}

\author{
Edwar CALDERÓN \\ University of Edinburgh School of GeoSciences \\ E-mail:e.calderon@ed.ac.uk
}

Received 22 November 2016; accepted 19 May 2017

\begin{abstract}
The Functional City principles steered the development of Latin American cities post WWII, but their influence in current urbanisation in LA has not been acknowledged or studied, due to the presumption by planners that contemporary planning operates within a very different planning paradigm to the earlier modernist one. In contrast, this paper argues that contemporary urban planning practices in Colombia are still dependent today on functionalist urbanism. Through a case study of three of the 28 approved Planes Parciales (sectorial plans) in Medellín, Colombia, based on primary data sources, I argue how the Functional City principles have been overshadowed by and formulated from a socio-economic perspective which creates discrepancies between local planners and academics regarding their application. This study contributes to a better understanding of current urbanisation patterns in Latin America. Furthermore, this study will invite reflection and public debate over questions such as: urbanization for whom/against whom and who decides?
\end{abstract}

Keywords: modernist urbanism, Latin American urbanism, Functional City, CIAM, Medellin, Colombia.

\section{Introduction}

In 1997, new planning legislation was introduced in Colombia - the Ley 388 de 1997 - addressing urbanism from a political, technical and administrative perspective. Its main goal was to regulate the intervention of the private sector, strengthen the participation of the state and encourage public participation in the planning process (Restrepo 2011: 62). This legislation established two instruments of planning in Colombia: the POT (Plan de Ordenamiento Territorial) and Planes Parciales (sectorial plans). The POT guidelines for the territorial arrangement of Medellín are based on a "collective imaginary model" aiming at competitiveness, environmental sustainability, social equality and a balance of land uses in the territory. As such, these goals are expected to be addressed in every single urban project executed in the city, including the Planes Parciales (Restrepo 2011: 101-102).

Jenkins et al. (2007), identify three progressive urbanist paradigms in Latin America during the 20th Century: "master planning", which corresponds to the Functional City associated with The International Congresses of Modern Architecture (CIAM); "sys- tems urbanism", which sought to expand the issues addressed by planners to include diverse social and economic processes; and, "negotiable urbanism", in which citizen participation becomes central (see Table 1). At first sight, and considering the time period in which the POT and Planes Parciales emerged and their emphasis in participation and dialogue, they can be understood as belonging to the third and final paradigm of urbanism. As this approach considers urbanism as a political decision-making programme, it takes into account that Ley 388/97 is based on principles of global market competitiveness and sustainability (Alcaldía de Medellín 2011: 197).

However, this paper will argue that contrary to received opinion and to the perception of current urbanism in Colombia, CIAM's Functional City - the first and widely discredited of the three paradigms - is still dominant in Medellín. Despite evident changes and transformations, key aspects of this early modernist theory are implemented in contemporary Medellín, present in the POT and Planes Parciales, even if in an implicit rather than explicit manner. In other words, this paper argues that Medellín's planning has not, 
Table 1. Urban Planning Paradigms in the "developing world" in the 20th Century and its corresponding implementation in Medellín, Colombia.

\begin{tabular}{|c|c|c|c|}
\hline Urban Planning paradigm & $\begin{array}{l}\text { Emerging point in the } \\
\text { "developing world"* }\end{array}$ & $\begin{array}{l}\text { Corresponding Urban } \\
\text { Planning Paradigms in } \\
\text { Medellín, Colombia }\end{array}$ & Influence \\
\hline $\begin{array}{l}\text { "Blueprint" - } \\
\text { master planning }\end{array}$ & After WWII & $\begin{array}{l}\text { 1950-1980s } \\
\text { - Plan Piloto, 1950 } \\
\text { - Plan Director, } 1959 \\
\text { - Plan Vial, 1969-1971 }\end{array}$ & CIAM \\
\hline "Systems" planning & Late $1960 \mathrm{~s}$ & Metropolitan Plan 1985 & British Structure Plans \\
\hline "Participatory" planning & $1990 \mathrm{~s}$ & $\begin{array}{l}1997 \text { onwards } \\
\text { - Plan de Ordenamiento } \\
\text { Territorial - POT (Land Use } \\
\text { Management Plan), } 1999 . \\
\text { "Physical" application } \\
\text { through Planes Parciales } \\
\text { (sectorial plans) - first in } \\
\text { 2003. }\end{array}$ & $\begin{array}{l}\text { - Spanish } \\
\text { Land Management } \\
\text { - Japanese } \\
\text { Land readjustment } \\
\text { - French } \\
\text { Land rights and Land banks } \\
\text { - USA } \\
\text { transfer of construction } \\
\text { rights }\end{array}$ \\
\hline
\end{tabular}

Note: *According to Jenkins et al. 2007.

despite claims to the contrary, progressed significantly beyond earlier and rejected forms of urbanism.

The paper proceeds to outline this argument by initially discussing the Functional City and identifying its core principles. It will continue by studying the POT and three Plan Parciales: Plan Parcial Altos de Calasanz, Plan Parcial San Lorenzo, and Plan Parcial SIMESA. The analysis will bring to the fore the perseverance of the logic of the Functional City in contemporary urbanism in Medellín, demonstrating that far from being embedded in the third paradigm of urbanism, contemporary urbanism is not only indebted to, but dependent on the logic of CIAM.

\section{The Functional City in Latin America}

CIAM, the pioneering organisation of progressive, modernist architects and planners, attempted to counteract the negative effects of industrialisation and mass-urbanisation via architecture and town planning. This interest led to the argument for the application of a "scientific approach" to town planning and a demand to break with traditions. At the centre of the CIAM position was the call to achieve absolute control of cities by organising them "rationally".

"Functionalism", as a general approach to architecture and urbanism - placing utilitarianism and efficiency at its centre and building on Taylorism and its 20th century sibling Fordism - was key to inter-war CIAM. CIAM's fourth congress (1933), "The Functional City", focused on urbanism and eventually resulted in two publications: Can Our Cities Survive? By Jose Luis Sert in 1942 (1947) and The Athens Charter by Le Corbusier in 1943 (1973). As part of this new functionalist approach to cities, CIAM proposed the classification and spatial separation of four urban functions: dwelling, work, leisure and circulation. The emergence of these four functions was promoted by the scientific management theories - Taylorism and Fordism. Cities' reorganisation was based on the model of a factory where each component or zone has a specific function, evoking, consequently, also an emergent aesthetic order (Guillen 1997: 685). By reducing city and life to four functions, the Functional City requires spatial organisation dividing the city into segregated monofunctional zones.

For CIAM, housing was the most important function of the city (Sert, International Congresses for Modern Architecture 1947: 12). This corresponds to what Frampton calls CIAM's first stage (1928-1933) CIAM was focused on "minimum living standards and optimum height and block spacing for the most efficient use of both land and material" (Frampton 1980: 270). The main problems that CIAM tackled through this function were density, spatial quality of dwelling (i.e. lack of sunlight and fresh air), arbitrary and inappropriate location of residential areas. Sert argued that the unsuitable location of housing was mainly due to a lack of urban legislation (Sert, International Congresses for Modern Architecture 1947: 54).

In order to improve the situation and solve problems of housing quantity and quality within cities, CIAM prescribed a series of requirements. Furthermore, two applicative scenarios for this function were named: open undeveloped zones and developed "blight" areas (Sert, International Congresses for Modern Architecture 1947: 70). Regarding the latter, on the problems of slum settlements, the charter proposed that "the only remedy for this condition is the demolition 
of the infected houses and the reconstruction" (Sert, International Congresses for Modern Architecture 1947: 24). The reconstruction should be based on the analysis of the particular conditions of each district to determine the most appropriate housing solution and density (Sert, International Congresses for Modern Architecture 1947: 60).

According to the architecture historian Eric Mumford, for CIAM, high-rise provides a better urban density, sunlight access and more green opened-linked areas for recreation (Mumford 2000: 38). This vertical growth of the city, was stimulated by the new construction techniques and materials as well as by the technological advances of the age of the machine (Sert, International Congresses for Modern Architecture 1947: 64). This promotion of verticality was an addition to the "Rationalisation and standardisation [that] were touchstones of the CIAM approach to building: reducing building tasks, simplifying functional elements, and generalising human dwelling habits" (Somol 1997: 254) which consolidated the pragmatic approach of CIAM to fulfil housing deficit in cities. Moreover, according to CIAM, the creation of zoning legislations would play a determining role in the selection of the most advantageous location in the city for housing (Sert, International Congresses for Modern Architecture 1947: 58).

Finally, for the housing function, Sert's publication (differing from Le Corbusier's) added the application of the "neighbourhood unit" concept to organise residential districts (Sert, International Congresses for Modern Architecture 1947: 58). This concept was largely applied in the Functional City plans for South American cities by CIAM in the late 1940s and early 1950s. According to Barnett, the idea of having neighbourhood units was borrowed from Clarence Perry (published in 1929) and the American Garden City Movement (Barnett 2011: 40). The "neighbourhood unit concept" consisted of grouping 5,000 to 6,000 inhabitants, which was considered the minimum population to support an elementary school. Each unit would have its own amenities and community services. A group of neighbourhood units would form precincts (districts) of 30,000 to 40,000 people, which together would constitute the city itself. (Sert, International Congresses for Modern Architecture 1947: 70).

For the second urban function, recreation, CIAM basically points to a lack of, and the inappropriateness of, recreational spaces in the city, as well as deficient connectivity to where they exist. "The provision of sufficient space for recreational purposes has become one of the most urgent problems of growing cities" (Sert, International Congresses for Modern Architecture
1947: 84). The creation of this space would be achieved through the densification of the city: vertical growth, proposed in the housing function, which would leave enough connected-green open space for this purpose (Le Corbusier 1973: 69). Also, in the "freed" green areas, community services such as nursery schools, elementary schools, public libraries, auditoriums, etc. were proposed (Sert, International Congresses for Modern Architecture 1947: 94).

Regarding the function of work, Le Corbusier made an important observation about the modern way of production: "mechanisation disrupted the harmonious link between dwelling and work together" (Le Corbusier 1973: 74). He emphasised the change that technological, political and economic development brought to the cities in production. This function is divided into three categories: an industrial area, a business district and governmental district. The main focus was on industry, which was the main source of labour and the reason for massive immigration to the cities. As pointed out by Sert, in his Functional City version of 1942 , the location of industries was unsuitable because the majority of industries were moved to the outskirts of the cities were taxes and land were cheaper (Sert, International Congresses for Modern Architecture 1947: 111). As a consequence of this, the working population was forced to endure lengthy commutes, something that Le Corbusier called "[...] the great ill of our time: the nomadism of the working population" (Le Corbusier 1973: 74).

The requirements for this function can be summarized as follows: a suitable location in terms of time-space and pollution control. Regarding the first factor: "The distances between dwellings and workplaces should be direct and traversable in a minimum of time" (Sert, International Congresses for Modern Architecture 1947: 150). Industry should therefore be located close to railroads, harbours, or transportation lines and business districts should be linked with housing and industrial areas by efficient transportation (Sert, International Congresses for Modern Architecture 1947: 153). Secondly, industrial districts should be separated from residential areas by green belts and they should have their own independent zone (Sert, International Congresses for Modern Architecture 1947: 152), while certain small industries could remain in closer proximity to housing districts.

In addition, the function of circulation represents the connection between the other three functions. Taking into account the increased speed of transportation and the conception of production in the machine age, the four functions focus on achieving efficiency by saving time. Therefore, for the functional city approach, 
distances justified the vehicular transportation usage. The Athens Charter proposed a safe organization of traffic encouraging the use of automobiles to make the relationship of time-distance inversely proportional.

This function deals with the inconvenience of street system design. The streets and roads of most cities were designed for other transportation modes (pedestrian, horse-drawn vehicles). Those streets no longer fulfil transportation requirements in the machine age and other design specifications are necessary, i.e. wider streets (Sert, International Congresses for Modern Architecture 1947: 162). Thus, the charter proposes increasing distances between intersections, that would reduce braking times, and therefore increasing the average speed of car (Le Corbusier 1973: 81). This corresponds to Le Corbusier's slogan: "[T]he city which can achieve speed will achieve success (Le Corbusier, Etchells 1971: 191).

A classification of streets according to their functions is provided: residential streets, industrial streets, business district streets, etc. (Sert, International Congresses for Modern Architecture 1947: 186). Also, a separate pedestrian network is deemed necessary (Sert, International Congresses for Modern Architecture 1947: 190).

Next to these four functions, a clear connection between CIAM and Latin-America can be found, which also led to the development of a new fifth function. In 1942, CIAM's members Jose Luis Sert, Paul Lester Wiener and Paul Schultz founded the firm Town Planning Associates (TPA). In 1943, TPA was contracted to design a civic centre for Motor City in Brazil (Fig. 1): a plan based on a typical (colonial) town square in Latin America (Mumford 2009). This project marked the beginning of a new, or more precisely, an evolved philosophy of the CIAM urban principles. This "evolution" consisted of a greater emphasis on the urban liveliness of city centres where pedestrians would play a leading role. This came to be the postwar philosophy of CIAM called "The Heart of the City" pioneered by Sert, Le Corbusier, Giedion and Wiener. "They began to suggest that some kind of pedestrian civic centre was a necessary component of modern cities for both cultural and political reasons" (Mumford 2009: 80). This new social approach would be reflected in the upcoming urban planning projects of TPA in South America. This approach deepened Sert's interest in and fascination with colonial Latin American plazas and resulted in Sert's postwar strategy "[...] a rich fusion of modernism and the vernacular [...]" (Mumford et al. 2008: 91). This constituted the creation of the fifth urban function, the civic centre, which would become a key element of the post-war CIAM urban design.
Moreover, there is a specific connection between CIAM and Colombia. In 1947 Le Corbusier was invited to Colombia by Dr Eduardo Zuleta Angel to give two conference lectures in Bogotá (Fig. 2). During this visit, negotiations to develop a master plan for Bogotá were taken up, and a new Colombian CIAM chapter was set up. Moreover, new legislation of planes reguladores ("second phase" of master plans) for new urban development (Mumford 2000: 211) were established. It was at this time (1947-1948) that CIAM's interest turned to Colombia despite the turbulent political situation caused by confrontations between the liberal and conservative parties (Rovira 2003: 136). In the same year

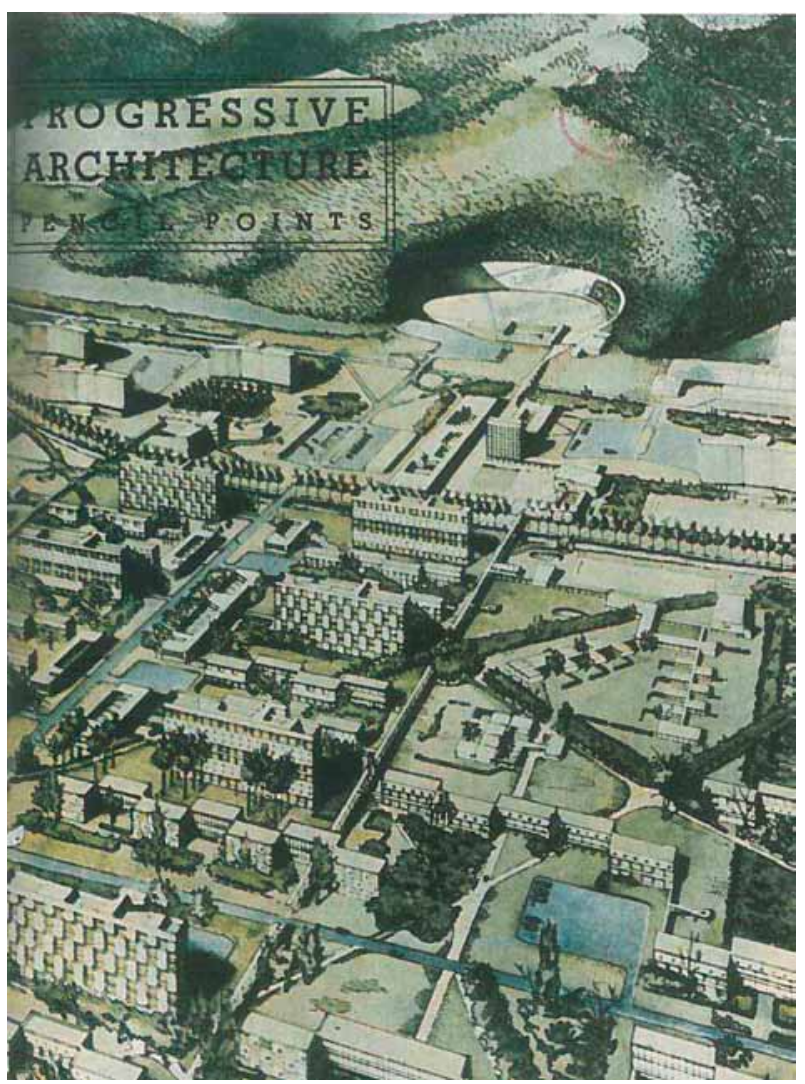

Fig. 1. Civic centre, Motor City project in Brazil by Town Planning Associates. Cover of the Progressive Architecture Journal September 1946 (Mumford 2009).

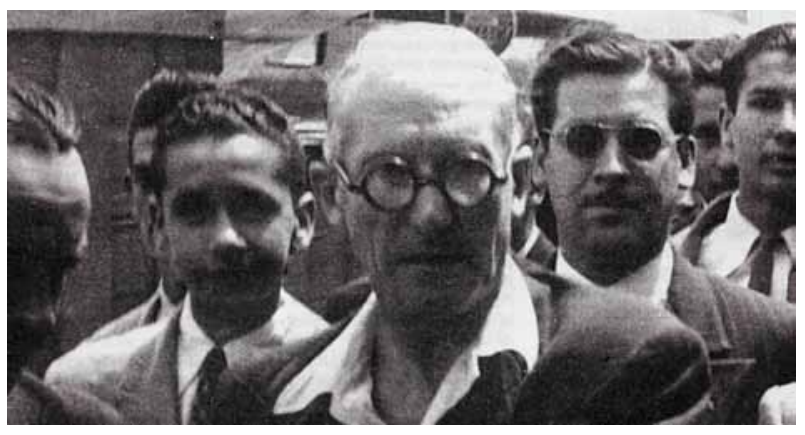

Fig. 2. Le Corbusier at the airport in Bogotá during his first visit to Colombia (1947). Revista Arcadia, May 22, 2015. 


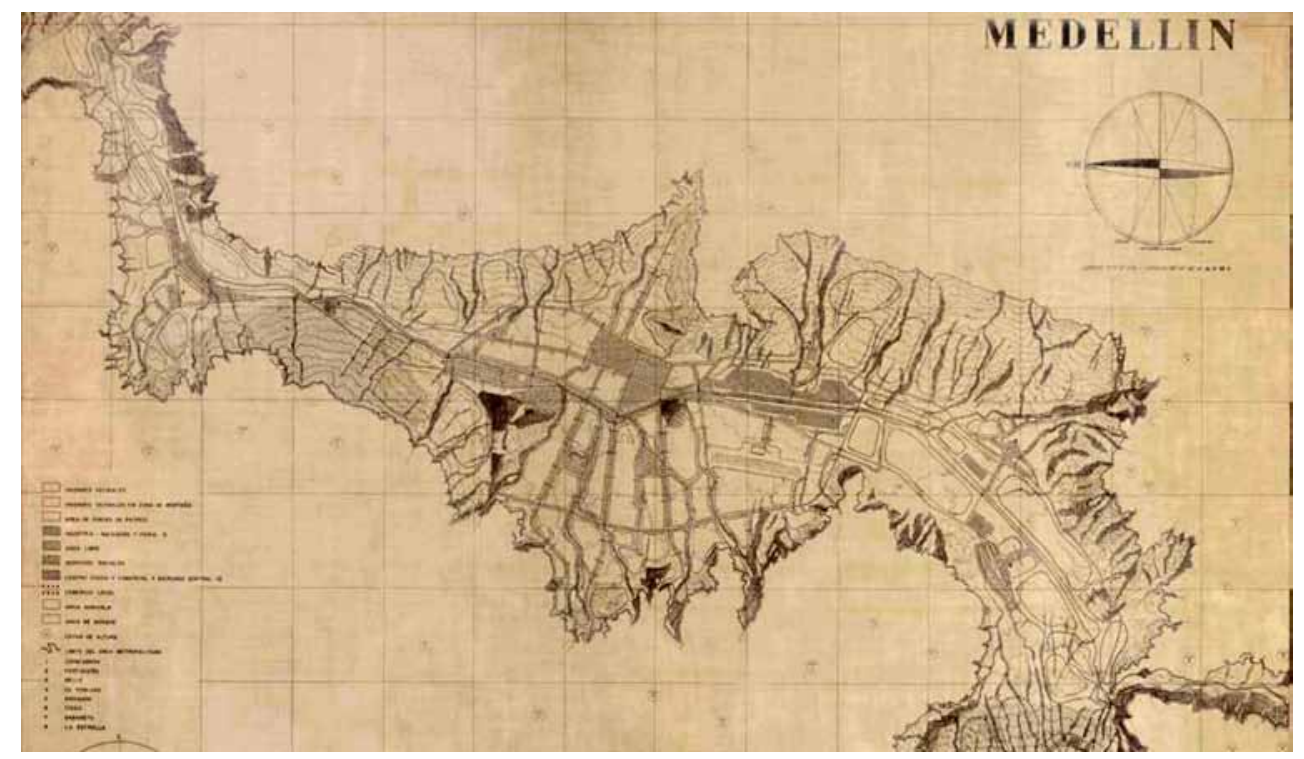

Fig. 3. Medellín Plan Piloto, 1950. Town Planning Associates. Land use plan (1948). Plan courtesy of Planning Office of Medellín, historical archives.

(1948) another contract that would prove important for Sert was signed: the Plan Piloto for Medellín. This project lasted for two years (1948-1950) and as a result of the lack of work for Le Corbusier, Sert and Wiener in the USA, they accepted further planning commissions in Colombia: the Plan Piloto for Bogotá (1949-1953) and Cali (1949-1950) (Mumford 2009: 89).

CIAM's master plan (Functional City) for Medellin was a significant contribution to the urban development of Medellín and its region. CIAM's plan is considered the first comprehensive urban plan in the 20th Century for Medellín (Fig. 3). After it was delivered in 1950, Medellín did not have any other holistic urban plan for the city until 1999 when the first Plan de Ordenamiento Territorial (POT) was formulated. Although urban planning in Medellín suffered from a gap of about 50 years, Functional City principles have been consistently applied - though not necessarily holistically and in some cases modified by local circumstances - in the city since 1950. This is shown in the successive plans from 1950 until today.

CIAM was discontinued in 1959 as a result of many divergences between its members, in particular between the older and younger generations. In 1953 the latter created a splinter group called Team 10 which was originally meant to be provide a "refreshing" viewpoint on CIAM. Team 10 initially ran in parallel with CIAM but gradually became one of the most radical critics of CIAM principles; they diverged from the "ruling authority of CIAM", which encouraged them to avoid any type of bureaucratic organisation (e.g. chairman, secretary) (Smithson, Architectural Association 1982: 1-2). The main criticism Team 10 made of CIAM was the categor- isation of urbanism in four urban functions - which they considered arbitrary. In their Statement on Habitat (Door Manifesto), they expressed dissatisfaction with the Functional City approach: "Urbanism considered and developed in the terms of the Charte d'Athens tends to produce "towns" in which vital human associations are inadequately expressed" (Smithson, Architectural Association 1982: 33). Rather they proposed a shift into a "human associations" categories that promoted a "re-thinking [of] the basic relationships between people and life" (Smithson, Architectural Association 1982: 40) promoting "a closer relationship between human activity and its geographical setting" (Mumford 2009: 113). It was a protest against the standardisation of urban problems, instead tackling every urban problem as an independent issue of a specific time and place (Smithson, Architectural Association 1982: 38). These categories meant to replace CIAM's four urban functions: housing, work, recreation and circulation by house, street, district, and city (Mumford 2009: 113)

The paper, following the brief summary of the Functionalist City's principles above, will now proceed to unfold the central argument regarding the prevalence of these principles in contemporary urban planning in Medellín. It will do so by analysing the introduction of the POT and its implementation in the case studies of three planes parciales: San Lorenzo, Altos de Calasanz and SIMESA.

\section{POT versus implementation}

Following the legislation Ley 88 de 1947 that promoted the implementation of the master plan in 1950, planning in Colombia was based on modern international 
models. They have been implemented through legislation based on economics and social circumstances that have changed local priorities permanently (Schnitter et al. 2007: 133) - i.e. road infrastructure as a symbol of economic development. This fluctuated approach determined planning in Colombia until 1997 when the legislation Ley 9 de 1989 was modified by Ley 388 de 1997 (Ley de Desarrollo Territorial) obligating Municipios (towns) with more than 100,000 inhabitants, to have a POT. The POT is the planning formula which has been followed since then. The current POT guidelines for the territorial arrangement of Medellín are based on a "collective imaginary model" which comprises the following 11 components (Alcaldía de Medellín 2006):

1. A rural zone with high environmental productivity: for the environmental agenda of the POT, the rural zones are potential environmental areas to be protected and improved in order to provide high environmental standards to their surroundings.

2. Designation of protected borders: every single municipality should set their internal urban perimeters in order to control urban expansion, and, to determine which areas are potential urban expansion zones for future urban development.

3. Spatial and environmental integration of the Medellín River: Medellín River is a determinant natural element that should be integrated into the urban structure of the city as a potential generator of public space, considering the preservation of its environmental features.

4. In-growth of the city (re-densification): in addition to the designation of urban borders to prevent chaotic urban expansion, the POT outlines a policy of "urban in-growth" which is the re-densification of the existing urban structure instead of expanding the urban borders.

5. A public space network that includes the hills located within the city: the public space network of the city should integrate the hills located within the city such as Cerro Nutibara, Cerro Pan de Azucar, and Cerro El Volador.

6. Assessment of the original urban structural elements of the city to be integrated with the Metro system.

7. A hierarchical system of centralities: the POT proposes it for administrative purposes and organisation of the territory.

8. Restoration of the traditional city centre: this item is perhaps one of the most challenging since the city centre has been redeveloped over the last three-four decades under economic policies that have made the area a monofunctional (work-related activities, ranging from services to finance capital) and deteriorated zone. One of the strategies to achieve this component is the promotion of social housing with state subsidies.

9. A medium capacity transportation system: at the time of writing, the METROPLUS (trolley bus systems) is under construction.

10. Metropolitan services corridor with high urban quality: one of the policies of the POT of Medellín is the redevelopment of the industrial zones located along the sides of the Medellín River. The redevelopment of this industrial zone implies a transformation of the land use into uses related to the Metropolitan Services Corridor. The Metropolitan Services Corridor is a new scheme defined in the POT for the promotion of the city as a regional and competitive platform aiming to achieve gradual transformation from an industrial city into a post-industrial services-based city. Consequently, the POT determines that the industrial zones located along Medellín River should be redeveloped when the existing industry closes or moves out. This transformation of land use should be arranged, using a plan parcial and must follow POT principles about inward growth of the city and a "healthy" land use mix.

11. "Healthy" land use mix: this component is not clear in the POT. Consequently, it is reasonable to assume from the literature review that healthy land use mix indicates a departure from rigid functional zoning and a preference of diverse spatially coinciding and overlapping land uses.

Furthermore, Zoraida Gaviria, in charge of the Planning Office of Medellín in 1997 and responsible for the introduction of the POT, clarified that the idea of healthy land use mix is a contemporary interpretation of the "compact city" principles. This approach was considered a more sustainable method for urban zoning (Calderón 2013b).

The above summary of the components of the Medellin POT contains some elements proposed in CIAM's 1950 master plan for Medellin, such as a hierarchical systems of centralities - neighbourhood unit, district, metropolitan corridor. Yet there are some elements which aim to rectify the perceived negative impact (direct and indirectly) of the application of the Functional City application in Medellin, such as the rigid zoning and the restoration of the traditional city centre through the so called "healthy land uses mix". 


\section{Prevailing Functional City principles in} the Planes Parciales

For this research a more thorough investigation of some specific Planes Parciales was conducted in order to determine if the Functional City principles proposed by CIAM have been reconditioned or reused in the current planning of the city. Three Planes Parciales were chosen from the 28 approved. The selected Planes Parciales for this study are: 1- San Lorenzo 2 - Altos de Calasanz and 3 - SIMESA (Fig. 4).

For this research a more thorough investigation of some specific Planes Parciales was conducted in order to determine if the Functional City principles proposed by CIAM have been reconditioned or reused in the current planning of the city. Three Planes Parciales were chosen from the 28 approved (see Table 2)

The three Planes Parciales were selected based on: diverse geographical conditions (location within the city; topography), different socio-economic contexts

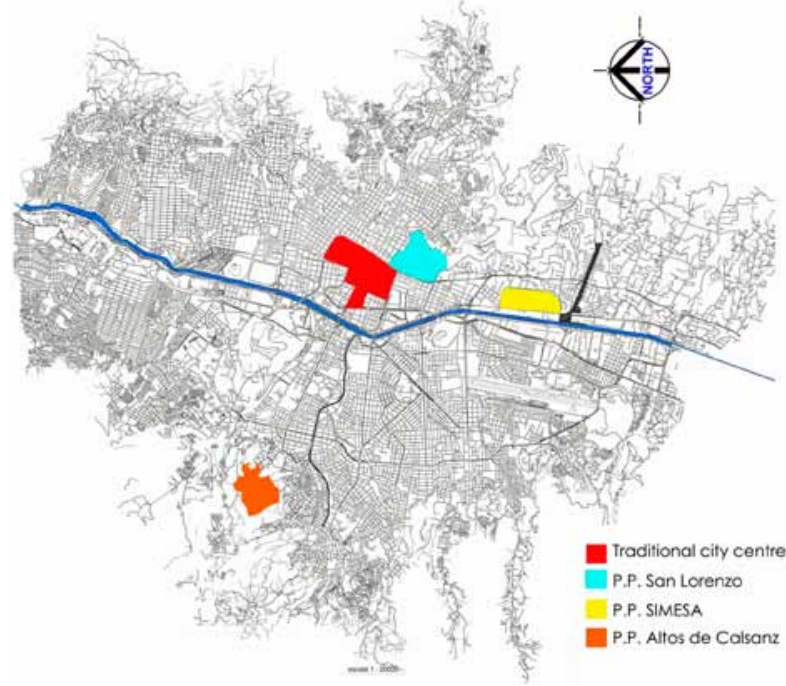

Fig. 4. Map of Medellín showing the areas covered by the three selected Planes Parciales; San Lorenzo, SIMESA and Altos de Calasanz as well as the traditional city centre. Map of Medellín from Plan Parcial SIMESA.

Table 2. Planes Parciales classification

\begin{tabular}{|c|c|c|c|}
\hline & PLAN & TYPOLOGY & \\
\hline 1 & Moravia & Comprehensive Improvement & Partially implemented \\
\hline 2 & Sevilla & Redevelopment & Under construction \\
\hline 3 & Plaza de Ferias & Redevelopment & No initiated yet \\
\hline 4 & Pajarito & Developemnt (Urban Expansion) & Under construction \\
\hline 5 & Everfit & Redevelopment & Partially implemented \\
\hline 6 & INDURAL & Redevelopment (industrial area) & Under construction \\
\hline 7 & San Lorenzo & Renovation & Partially implemented \\
\hline 8 & Paseo Sevilla & Redevelopment & completed \\
\hline 9 & Torres de la Fuente & Redevelopment & Partially implemented \\
\hline 10 & Guayaquil Poligono & Renovation & Partially implemented \\
\hline 11 & Guayaquil Manzana & Experimental project & completed \\
\hline 12 & Corazon de Jesus & Renovation & Partially implemented \\
\hline 13 & Asomadera & Development & Under construction \\
\hline 14 & Naranjal & Renovation & Under construction \\
\hline 15 & Parque de los Colores & Redevelopment & completed \\
\hline 16 & Altos de Calazans & Development (urban expansion) & Under construction \\
\hline 17 & INVATEX & Redevelopment (industrial area) & Partially implemented \\
\hline 18 & ARGOS & Redevelopment & Partially implemented \\
\hline 19 & SIMESA & Redevelopment (industrial area) & Under construction \\
\hline 20 & Villa Carlota & Redevelopment & Partially implemented \\
\hline 21 & La Cumbre & Development & Under construction \\
\hline 22 & Sta Maria de Los Angeles & Redevelopment & Under construction \\
\hline 23 & Loma de los Gonzalez & Consolidation & Under construction \\
\hline 24 & Altos del Poblado & Development & Under construction \\
\hline 25 & San Lucas & Development and Consolidation & Under construction \\
\hline 26 & Vizcaya & Plan Special & Permit expired and never implemented \\
\hline 27 & Loma de los Bernal & Development & completed \\
\hline 28 & Ciudadela Rincon & Development (urban expansión) & Under construction \\
\hline
\end{tabular}

Source: by author. 
(estratificacion socio-economica), disparate technical-administrative contexts (for example, in San Lorenzo: a renovation and re-densification of a deteriorated historical city-centre area), diversity of size and scale, and differences in the leading agencies (a governmental initiative for San Lorenzo, while Simesa and Altos de Calasanz are private initiatives) (Fig. 4 and 5, Table 3). In the cases discussed here, San Lorenzo constitutes the lowest socio-economic level and SIMESA the highest. Accordingly, this diversity of socio-economic contexts will provide different perspectives of how Medellín's urbanism is conceived today. Regarding the technical-administrative context, while in San Lorenzo, the plan aimed at increasing the urban-density-generating social housing in order to attract new residents into the area (Table 4), in Altos de Calasanz the focus was urban expansion (Table 5). This plan is located in one of the zones that the POT assigned for future expansion of the city with housing as the main function. In the case of SIMESA, the project was, essentially, a redevelopment of an industrial zone in accordance with the POT's guidelines regarding the "Metropolitan Services Corridor" (Table 6). The different sizes of the plans determine the scope of the projects in question. In the case of San Lorenzo, the plan covers three neighbourhoods, though in this paper the focus is on the Colon neighbourhood (commonly known as Niquitao) which has an area of 4.8 hectares. The Altos de Calasanz plan covers an urban-rural (city's peripheral area) of 81.5 hectares approximately, while SIMESA's plan covers a whole industrial block of about 30 hectares (Fig. 8).

In addition to the mentioned selection criteria, the selected Planes Parciales were not only approved but also under construction. This would permit a more tangible assessment of the central argument of this paper - the endurance of the modernist planning paradigm in Medellín - and its response in different locations within the city. Furthermore, each selected plan represents one of the main types of Planes Parciales in Medellín (Renovation, Development and Redevelopment) defined by the POT.
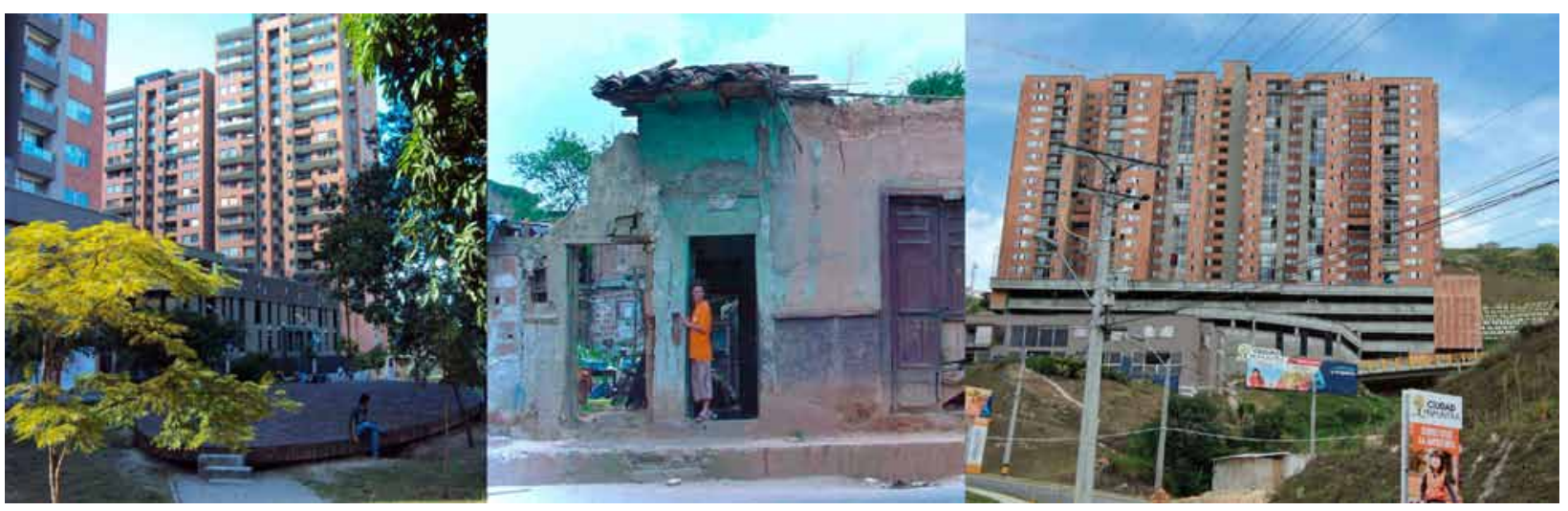

Fig. 5a. (left) Plan Parcial SIMESA

Fig. 5b. (centre) San Lorenzo housing deteriorated conditions

Fig. 5c. (right) Plan Parcial Altos de Calasanz

Table 3. Comparative criteria for the selection of the three Planes Parciales

\begin{tabular}{|c|c|c|c|c|c|}
\hline Plan & Type/goal & $\begin{array}{l}\text { Geographical } \\
\text { Location within the city }\end{array}$ & $\begin{array}{c}\text { Socio-economic level } \\
\text { (estratificación económica) }\end{array}$ & $\begin{array}{l}\text { Size/ } \\
\text { Scale }\end{array}$ & $\begin{array}{l}\text { Leading } \\
\text { agency }\end{array}$ \\
\hline $\begin{array}{c}\text { San } \\
\text { Lorenzo }\end{array}$ & Renovation & Centre-periphery & $\begin{array}{l}\text { (very) Low income } \\
\text { community }\end{array}$ & $\begin{array}{c}\text { (4.8 hectares) } \\
\text { Niquitao } \\
\text { Neighbourhood }\end{array}$ & $\begin{array}{l}\text { Local } \\
\text { government }\end{array}$ \\
\hline $\begin{array}{l}\text { Altos } \\
\text { De } \\
\text { Calasanz }\end{array}$ & $\begin{array}{l}\text { Development } \\
\text { (urban } \\
\text { expansion) }\end{array}$ & Periphery & Middle class & 81.5 hectares & $\begin{array}{l}\text { Private } \\
\text { developer }\end{array}$ \\
\hline SIMESA & $\begin{array}{c}\text { Redevelopment } \\
\text { (of industrial } \\
\text { area) }\end{array}$ & $\begin{array}{l}\text { South (close from city } \\
\text { centre) }\end{array}$ & Middle-upper class & 30 hectares & $\begin{array}{l}\text { Private } \\
\text { developer }\end{array}$ \\
\hline
\end{tabular}

Source: by author. 
Table 4. Plan Parcial San Lorenzo

\begin{tabular}{ccc}
\hline PLAN PARCIAL & GOAL & PLANNING STRATEGY \\
\hline SAN LORENZO & $\begin{array}{c}\text { This aims for a } \\
\text { renovation and re- } \\
\text { densification of the } \\
\text { Niquitao area }\end{array}$ & $\begin{array}{c}\text { The plan proposes increasing the urban density through the } \\
\text { construction of social housing buildings targeting both old and new } \\
\text { residents into the sector. In terms of renovation, this plan proposes } \\
\text { the demolition of deteriorated buildings and the construction of new } \\
\text { high-rise housing buildings ('slum clearance' approach) to free up the } \\
\text { ground level for public space and community facilities (see Fig. 6). }\end{array}$ \\
\hline
\end{tabular}

Source: by author.

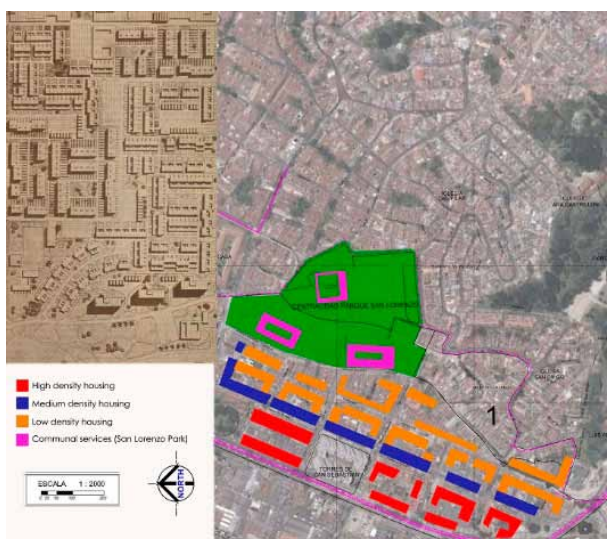

Fig. 6. Plan Parcial San Lorenzo. Polígono of Renovación Z3-R6. Housing scheme proposed sector Niquitao and Neighbourhood Unit model for Medellín. Sert and Wiener, Pilot Plan 1950.

Sources: Background map courtesy of EDU - Empresa de Desarrollo Urbano de Medellín - (2003). Alcaldía de Medellín. 2003. Highlights by author.

Table 5. Plan Parcial Altos de Calasanz

\begin{tabular}{ccc}
\hline PLAN & GOAL & PLANNING \\
PARCIAL & $\begin{array}{c}\text { To contribute to } \\
\text { solve the deficit of } \\
\text { housing that the } \\
\text { city of Medellín } \\
\text { currently faces. }\end{array}$ & $\begin{array}{c}\text { Ddevelopment of } \\
\text { urban expansion area } \\
\text { defined in the POT. }\end{array}$ \\
\hline CALASANZ & \\
\hline
\end{tabular}

Source: by author.

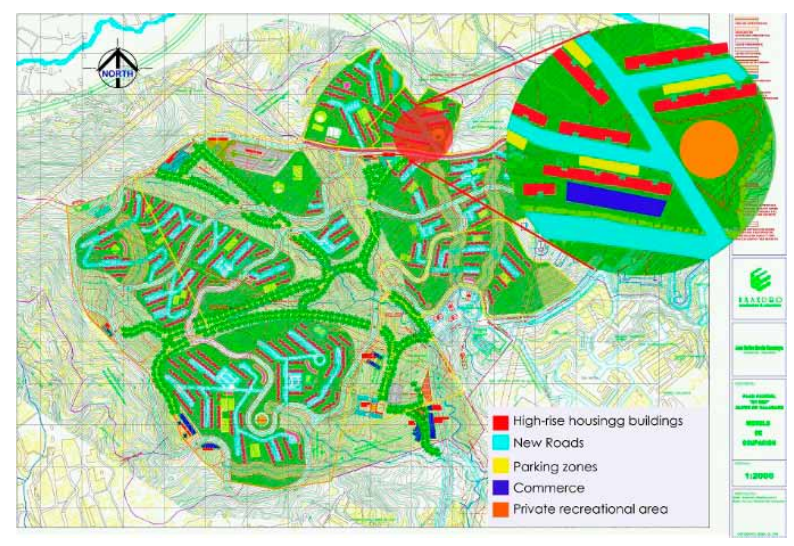

Fig. 7. Plan Parcial Altos de Calasanz. General proposal. Housing area schematic detail.

Source: Exaedro 2007 (highlights and modifications by author).

Table 6. Plan Parcial SIMESA

\begin{tabular}{ccc}
\hline PLAN & GOAL & $\begin{array}{c}\text { PLANNING } \\
\text { STRATEGY }\end{array}$ \\
\hline SIMESA & $\begin{array}{c}\text { This plan aims the } \\
\text { redevelopment of an } \\
\text { industrial zone close } \\
\text { to the city centre to be } \\
\text { realised over a period } \\
\text { of } 15 \text { to } 20 \text { years }\end{array}$ & $\begin{array}{c}\text { Transformation } \\
\text { of the existing } \\
\text { industrial zone } \\
\text { along Medellín } \\
\text { River into a } \\
\text { Metropolitan } \\
\text { Services Corridor }\end{array}$ \\
\hline
\end{tabular}

Source: by author.

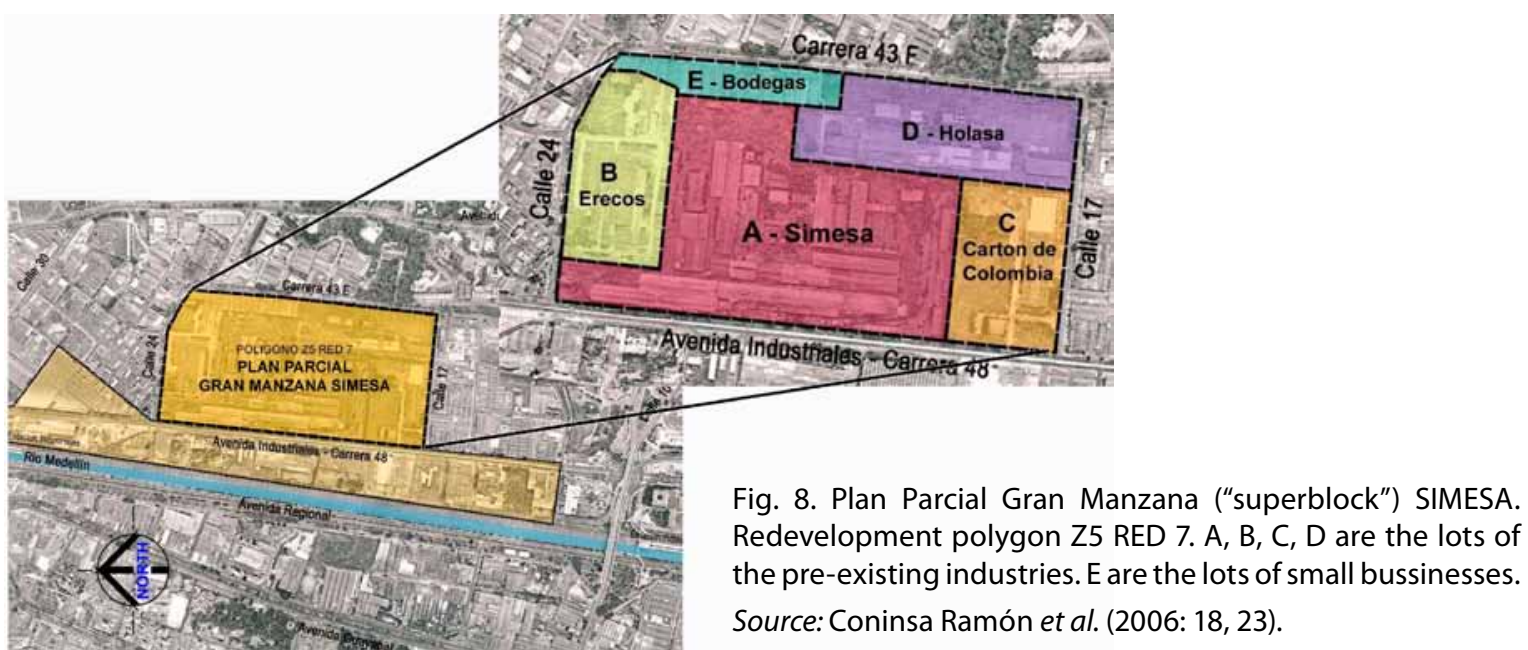


In the studied Planes Parciales, the four urban functions of CIAM can be perceived as follows.

\section{Housing}

The three selected Planes Parciales can be categorised according to the two Functional City housing development scenarios, open undeveloped zones and developed "blight" areas (Fig. 9). In the first scenario, the Plan Parcial Altos de Calasanz, which is an expansion zone of the city, the application of housing function is based on high-rise housing surrounded by green areas, connected by pedestrian and vehicular roads. In the second scenario, the Plan Parcial San Lorenzo, the application of the housing function proposes a radical approach of demolishing complete blocks of housing (slum clearance), to build high-rise social housing buildings. They follow a similar layout to the Neighbourhood Unit prototype proposed by CIAM in the Pilot Plan for Medellín in terms of: physical arrangement of buildings (i.e. shapes, mixture of building densities - high, medium and low - according to their location), freeing open space on the ground floor through use of higher densities, transformation of the existing grid into bigger housing blocks ("superblocks"), roads organised into a hierarchical scheme and local communal services within walking distance from housing.

The Plan Parcial SIMESA, could be considered a mixture of both scenarios because the zone is neither undeveloped nor of "blight". This scenario is the product of a "voluntary" relocation of an industrial estate. The application of housing function in SIMESA's plan is a "speculative" approach (uncertain percentage of land uses) that consist of housing superblocks surrounded by an urban park and connected by pedestrian paths.

These three housing applications share with the Functional City the neighbourhood unit as a distinct category. Considering that CIAM stipulate clearly in the Athen's Charter that each neighbourhood unit would vary according to local characteristics (phys- ical, socio-economic), the differences between densities, building typologies, and communal services proposed in each plan allow for evaluation under the same criteria. However, it is important to note that the housing function, which for CIAM was the primary function that subordinates the others, differs from Plan Parcial SIMESA. This latter places the work function as the priority, and targets via the housing a middle-high socio-economic population.

Moreover, the POT's urban density policy is unclear. The POT states that new developments must be oriented towards an inward growth of the city characterised by a rational use of the land to counteract urban expansion. However, the Plan Parcial Altos de Calasanz is located in one of the designated future urban expansion zones of the city. It shows a contradiction between the norm and the implementation, in other words, plan parcial Altos de Calasanz does not stop the urban expansion of the city, but instead stimulates it. On the other hand, it seems that the "rational use of the land" is understood as the minimum occupation (of land) rates along with a high construction density. Arguably, this interpretation of urban density is a product of CIAM's legacy: the "high-rise fever" (Somer 2007: 38-39) combined with a maximisation of profitable interests of the land.

\section{Recreation}

With the creation of the strategic plan for Medellín in 1995, the public space re-emerged as a vital component of urban planning. This signalled the return of the recreation function which had 'disappeared' in Medellín for more than three decades. Latterly, with the implementation of POT, public spaces became a requirement for all new developments.

In the three studied Planes Parciales, recreation is supported by public spaces that are generally green areas where communal facilities are located (Fig. 10). For instance, the Plan Parcial Altos de Calasanz proposes linear parks along the borders of the creeks and

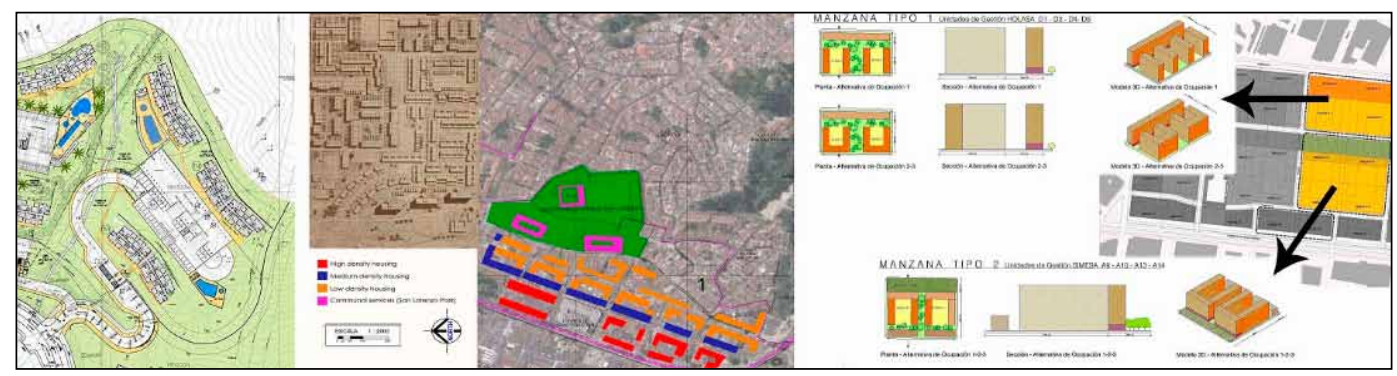

Fig. 9. Housing proposal for the three planes parciales: 9a (left) Altos de Calasanz, 9b (centre) San Lorenzo and 9c (right) SIMESA.

Sources: Exaedro 2007, Alcaldía de Medellín 2003 and Coninsa Ramón H., Londoño Gómez and Arquitectura y Concreto 2006. 


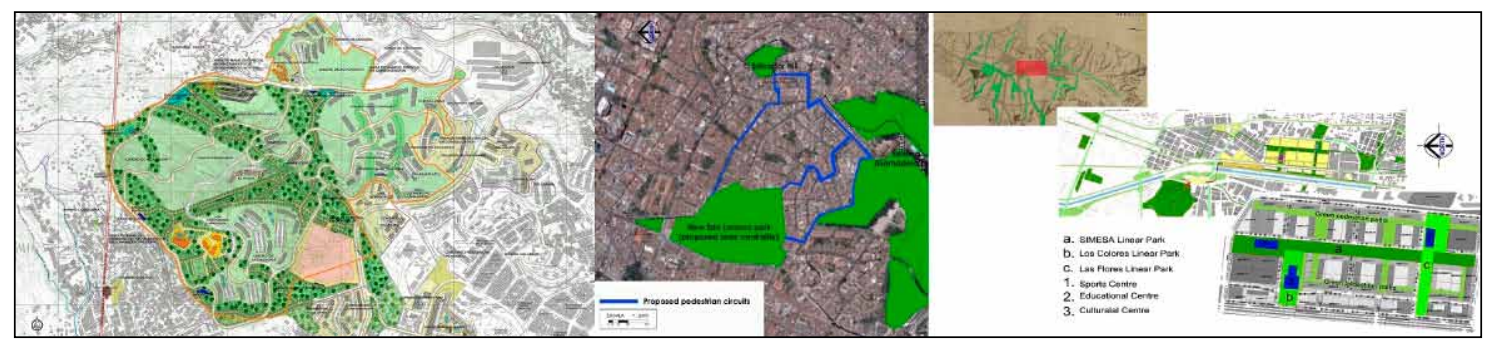

Fig. 10. Recreation function proposed in the three planes parciales: 10a (left) Altos de Calasanz, 10b (centre) San Lorenzo and 10c (right) SIMESA

Sources: Exaedro 2007, Alcaldía de Medellín 2003 and Coninsa Ramón H., Londoño Gómez and Arquitectura y Concreto 2006.

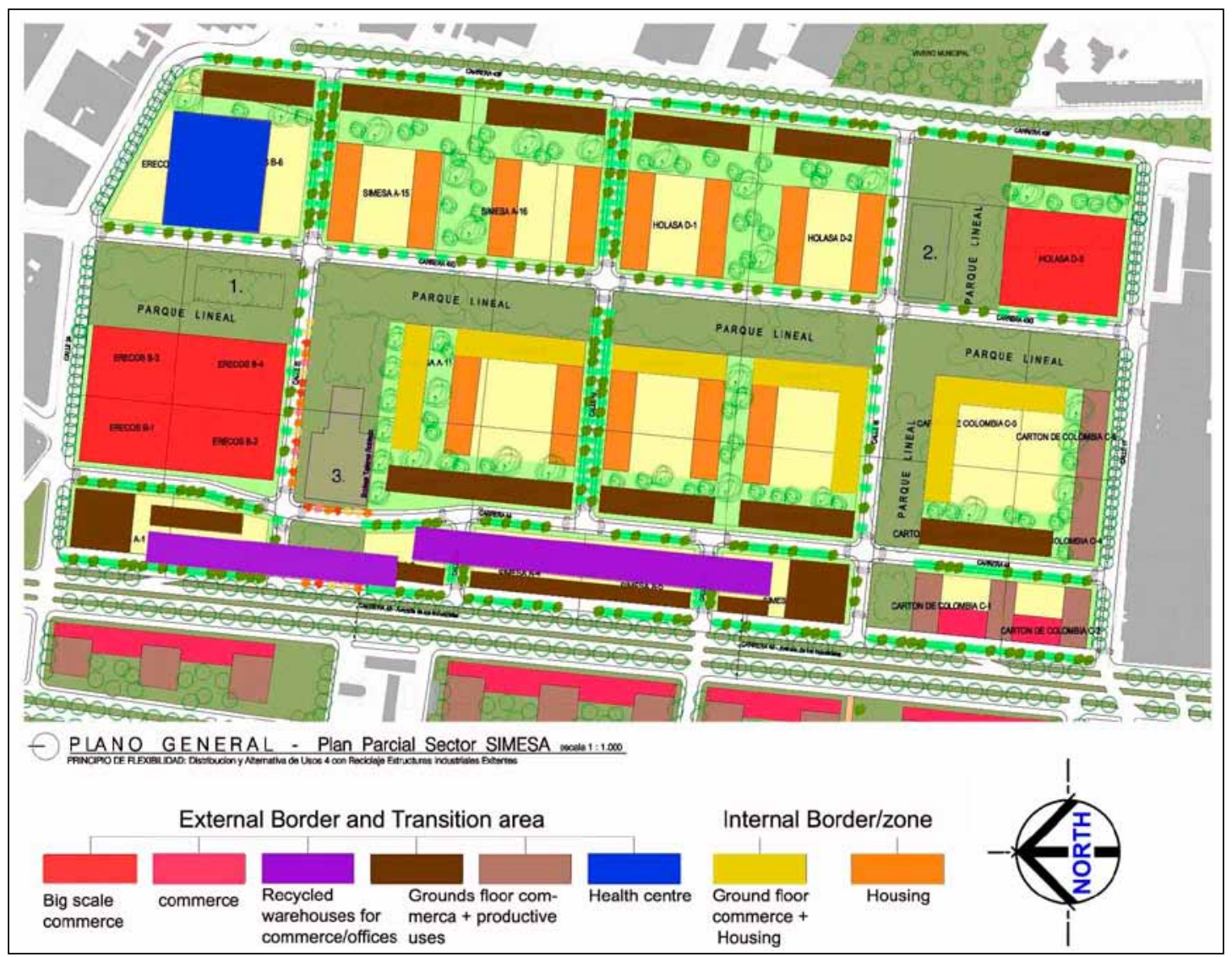

Fig. 11. Land use plan for SIMESA plan parcial

Source: Coninsa Ramón H., Londoño Gómez and Arquitectura y Concreto 2006.

a vast green area where the communal services will be located. This is very similar to CIAM's Pilot Plan description. In the Planes Parciales SIMESA and San Lorenzo, the linear parks proposed envisage a future interconnected green network for recreational and pedestrian mobility purposes, in which the communal facilities will be located. This is also in accordance with the proposals detailed in CIAM's Master Plan. In general, the recreation function proposed in the studied Planes Parciales follows the ideas advised by CIAM more than 60 years earlier in the Master Plan for Medellín.

\section{Work}

This function is perhaps the least evident Functional City principle in the Planes Parciales, with the exception of the Plan Parcial SIMESA (Fig. 11). This function has changed the most of the four Functional City urban functions in Medellín. The explanation can be attributed to the economic restructuring, which has transformed Medellín from Colombia's industrial city to a city with a service-based economy. Furthermore, environmental legislation presses for relocation of heavy industry outside of the city limits. These circumstances have changed the concept of the Functional 
City work function, making the function less harmful and more compatible with housing and recreation. However, Medellín still faces some work monofunctional zoning such as the city centre and the southern industrial zone such as Guayabal and Itagüí which is a legacy of CIAM's Master Plan.

The POT guidelines emphasise the "healthy land uses mix" which every single Plan Parcial should achieve. This means that different land uses can be tolerated as long as they do not represent a conflict for the development of the other uses. By achieving the land use mix suggested in the POT, the city will have employment sources closer to residential areas thus limiting daily commutes. However, this intention is presented at a very fine scale, limited to commerce (retail) on ground floors or single isolated buildings (except for the Plan Parcial SIMESA). In general, the work function is presented strongly in Planes Parciales, located within medium to high socioeconomic areas. However, contrary to the Athen's Charter recommendations, these working places do not necessarily target local inhabitants' employment, which stimulates urban commuting.

\section{Circulation}

The three Planes Parciales show a significant increase of the road infrastructure, showing the importance of this function for every development in the city. The number of roads (new and/or expansion of existing ones) is increasing in all areas regardless of the so- cioeconomic level of the area, driven by private economic interest (i.e. new housing developments).

The planes Parciales present a contradictory goal of promoting public transportation and pedestrian connectivity while encouraging private vehicular use. Arguably, the Planes parciales are designed based on vehicular mobility, with public transportation, and pedestrianisation as an afterthought. In addition to the vehicular planning orientation, the road systems are designed in a hierarchical scheme, defining section and function of each road, similar to the Functional City scheme proposed by CIAM in the Master Plan for the city.

\section{Civic centre}

A neighbourhood civic centre scheme, derived from the Neighbourhood Units of Sert and Wiener, has been followed in all the Planes Parciales examined. These civic centres have cultural, recreational and communal facilities for the local inhabitants. However, the civic centre at city scale proposed by Wiener and Sert for Medellín was built (with modifications from its original design) more than 20 years later (1974-1978) (see Fig. 12). This civic centre - which had recently become "The fifth function" of CIAM's Functional City - promoted the ideas of "city pride and image" that should be materialized in a monumental urban centrality, corresponding to the strong industrial development that the city was facing by that time. The civic centre would also have several public buildings. It became the national, departmental and municipal administrative complex of Medellín.

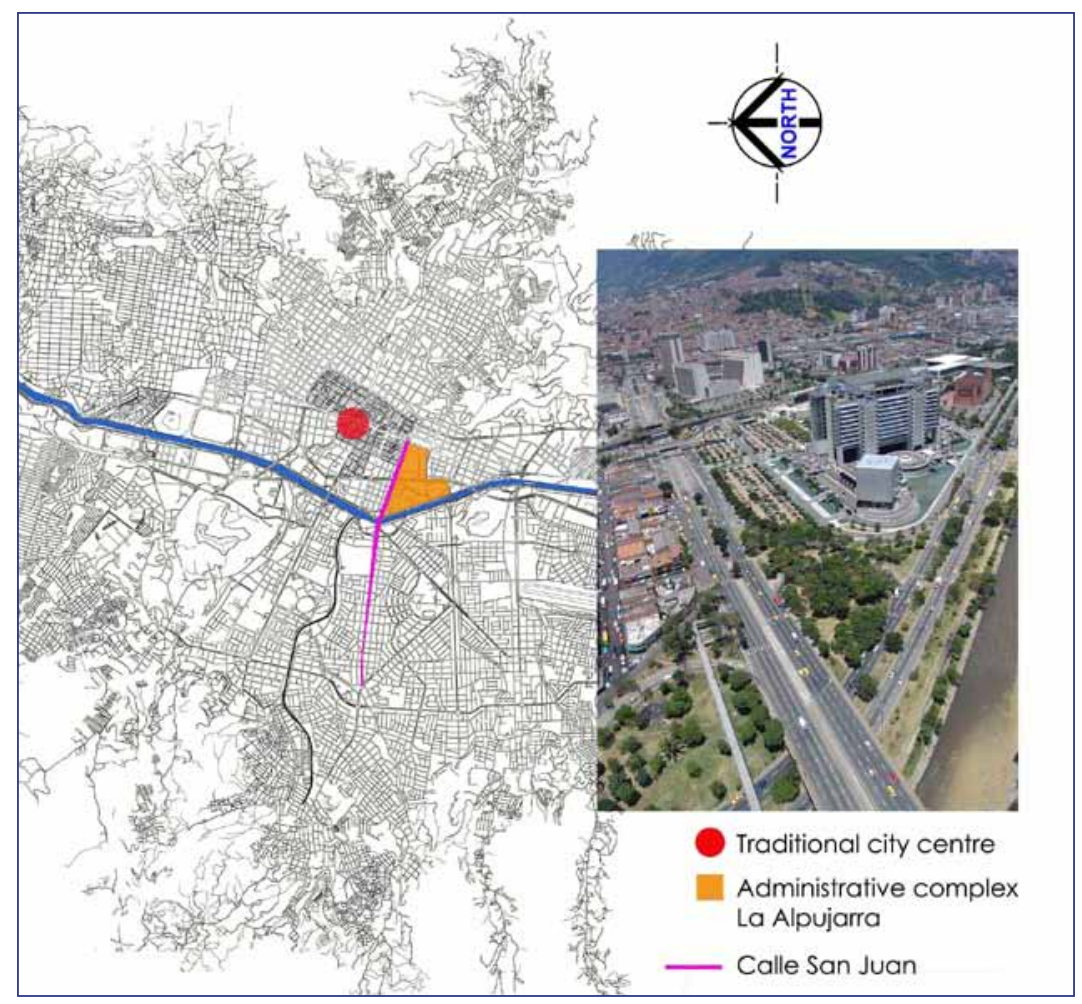

Fig. 12. Medellín's Civic centre following CIAM's proposal

Source: Map of Medellín from Plan Parcial SIMESA, aerial photo courtesy of Medellín's Planning Office. 
Table 7. Comparison of Functional City aspects of the selected Planes Parciales

\begin{tabular}{|c|c|}
\hline FUNCTION & P. P. SAN LORENZO \\
\hline HOUSING & $\begin{array}{l}\text { Demolition of deteriorated buildings and the } \\
\text { construction of new high-rise housing buildings } \\
\text { ("slum clearance"), to free up the ground level for } \\
\text { public space and community facilities. The housing } \\
\text { proposal scheme resembles the Neighbourhood } \\
\text { Unit prototype proposed by CIAM in the Pilot Plan } \\
\text { for Medellín (see Figs 5b and 6); } \\
\text { 1. Similar physical arrangement of buildings (e.g. } \\
\text { shapes, mixture of building densities - high, me- } \\
\text { dium and low - according to their location) } \\
\text { 2. Freeing open space on the ground floor through } \\
\text { use of higher densities } \\
\text { 3. Transformation of the existing grid into bigger } \\
\text { housing blocks ("superblocks") } \\
\text { 4. Roads organised into a hierarchical scheme } \\
\text { 5. Local communal services within walking distance } \\
\text { from housing }\end{array}$ \\
\hline
\end{tabular}

WORKING* This function is not referenced in this Plan Parcial

The plan proposes to concentrate some commerce in the civic centre to provide dynamism (Exaedro 2007: 92-93). The civic centre would be comprised of light commerce, offices, services, cultural, recreational and handcraft industries, among others. (Exaedro 2007: 114-115). This proposal of creating local working places was described as a goal of CIAM's work function. CIAM proposes the creation of local employment by means of locating working and housing places so that they are "direct and traversable in a minimum of time" (Sert, International Congresses for Modern Architecture 1947: 150).

\begin{tabular}{ll}
\hline RECREATION & Linear parks proposed envisage a future intercon- \\
& nected green network for recreational and pedes- \\
& trian mobility purposes, in which the communal \\
& facilities will be located.
\end{tabular}

This plan proposes linear parks along the borders of the creeks and a vast green area where the communal services will be located. This is very similar to CIAM's Pilot Plan description.

CIRCULATION** In addition to the vehicular planning orientation, the road systems are designed in a hierarchical scheme, defining section and function of each road, similar to the Functional City scheme proposed by CIAM in the Pilot Plan for the city

CIVIC CENTRE One of the main features of this plan parcial is the proposal of a civic centre - Centralidad Parque San Lorenzo - which will be located at the site of the former San Lorenzo cemetery. It will conserve and renovate the old cemetery structure because of its historical value to the city. This public space is similar to CIAM's proposals of civic centres for the Neighbourhood Units in their Latin-American plans. The Centralidad Parque San Lorenzo will have a similar function and layout: communal and institutional amenities for the local residents will be constructed and this space will also provide a location for gatherings of the local population (Alcaldía de Medellín 2003: 94). The San Lorenzo neighbourhood civic centre will be connected by pedestrian and vehicular roads to the administrative centre La Alpujarra, which was the city's civic centre proposed by CIAM and built in the 1970s. (similar to Plan Parcial San Lorenzo) Lorenzo)

The civic centres proposed by CIAM for the Neighbourhood Units in Latin America have similar characteristics to those proposed in the Plan Parcial Altos de Calasanz. The community facilities are located as suggested in the Pilot Plan for Medellín, within green parks and within walking distance of residential buildings. In this specific case, they are found in the most suitable location in terms of topography as well as vehicular and pedestrian accessibility. (similar to Plan Parcial San Lorenzo)

The main urban function of this plan parcial is work. The areas proposed in this plan parcial related to the work function are: 2,203 offices of $60 \mathrm{~m}^{2}, 572$ commercial premises of $100 \mathrm{~m}^{2}$ and 34 warehouses of $1000 \mathrm{~m}^{2}$ (Coninsa Ramón H., Londoño Gómez and Arquitectura y Concreto, 2006: 196).

(sin

(similar to Plan Parcial San
Lorenzo)

The civic centre in this plan parcial is less explicit, although there are cultural, recreational and communal facilities for the local inhabitants: cultural (museum) sports fields and educational (Technological educational centre).

\footnotetext{
Source: by author.

* In general, the work function is presented strongly in Planes Parciales, located within medium to high socioeconomic areas.

** The three Planes Parciales show a significant increase of the road infrastructure, showing the importance of vehicular mobility (no public) for every development in the city. The number of roads (new and/or expansion of existing ones) is increasing in all areas regardless of the socioeconomic level of the
} area, driven by private economic interest (e.g. new housing developments). 
The findings suggest that the application of CIAM's Functional City principles in Medellín reflect a lack of historical and contextual (mainly socio-economic and cultural) awareness necessary to build a coherent, effective, and appropriate approach for the city. Moreover, they suggest that the acceptance and implementation of the Functional City principles in the 1950s, 1960s and 1970s in Medellín has meant that concepts of rational efficiency, standardisation, fragmentation (zoning), monotony, damage to historical environments, have also been applied since then in the urban planning of the city. The strong roots that the Functional City planted in Medellín seem to be justified in considering the Master Plan of Wiener and Sert as the first comprehensive urban planning approach for the city. This approach established a generally dominant modernist doctrine among local planners. However, in consideration of the inadequacy of the plans, their disjunction with local conditions and reality, findings reveal the willingness of local planning authorities to break the dominant functionalism of the urban planning of Medellín (i.e. rigid zoning) (Calderón 2012d). Zoning, for instance, has been used in Medellín as a resistance to new global economic paradigms: in the last revision of the POT (2006), the plan promoted the protection of the industrial zones as mono-functional areas, although the local economy of Medellín has been transformed into service-based economy. This suggests an unawareness of the macro-economy (global market) in which Medellín is placed, and the prevalence of an outdated and much-maligned form of zoning associated with CIAM.

\section{POT as FUNCTIONAL CITY in New Guise}

In the half century separating Sert's and Wiener's plan and the next attempt at restructuring planning via legislation in Colombia, the discipline and practice of urban planning experienced several transformations. The complex political situation that Colombia had faced during that period was a key factor in the weak role of the state over private interests. An example of this is the almost forty-year delay in accepting an urban reform which was finally implemented in 1989. Similarly reforms took place much earlier in other countries. For instance in UK, The Skeffington Report and the subsequent Planning Act 1968 (1969 in Scotland).

The partial application of plans has been a recurring tendency in the urban development of Medellín, and in this sense the Functional City proposal for Medellín was no exception. Over the last 60 years, the city has suffered from "patchy", piecemeal planning, evidenced in the partial application of Plan Piloto, Plan Regulador,
Plan Vial and currently in the application of Planes Parciales.

The summary of components of the POT contains some elements proposed in CIAM's master plan for Medellin in 1950 i.e. hierarchical systems of centralities - neighbourhood unit, district, metropolitan corridor, spatial and environmental integration of the river, green network and public space system integrating the hills located within the city. Yet there are some elements which aim to fix the negative impact (direct and indirectly) of the Functional City application in the city such as the rigid zoning and the restoration of the traditional city centre through the so called "healthy land uses mix".

The separation of functions is still more evident in the urban expansion plans in Medellín. For instance, the Plan Parcial Pajarito and the mentioned Plan Parcial Altos de Calasanz, currently under development. The former, would be another mono-functional massive housing project which envisages about 8,000 housing units using the Functional City principles (Figs 13 and 14). Both plans recall CIAM's strategy to counteract housing shortage in the city through Taylorist and Fordist approaches. Moreover, this segregation of functions have been stimulated by strong road infrastructure development that has permitted the spread of housing projects all over the city encouraging urban expansion (see also Fig. 15b. Plan Parcial Loma de los Bernal).

The study appears to support the argument that Functional City principles are still present in the urban development of Medellín since an "anti-Functional City" alternative or another urban planning alternative has not been developed yet due to the lack of technical training and supportive urban legislation (i.e. the incapability of local planners to create the legal mechanisms

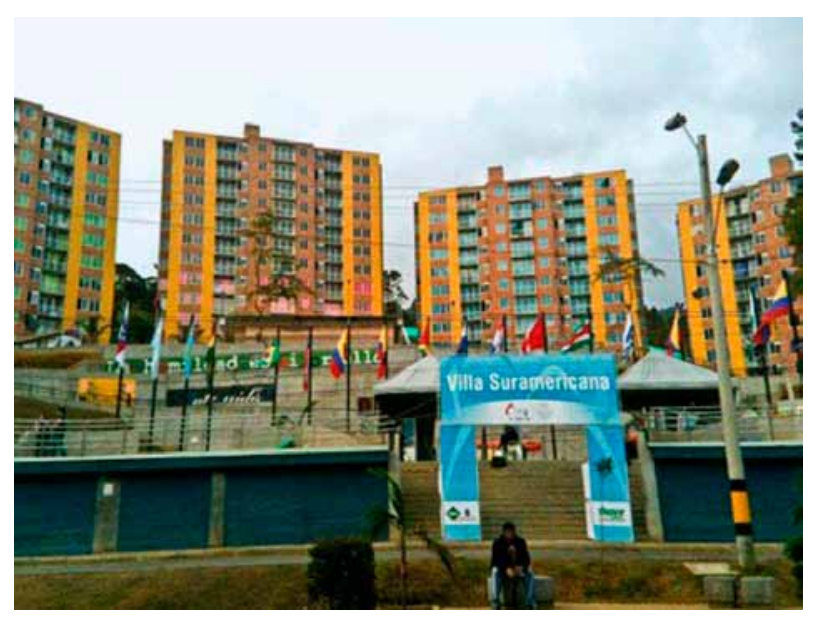

Fig. 13. Plan Parcial Ciudadela de Occidente "Pajarito". Photo courtesy Grupo UR, Medellín. 

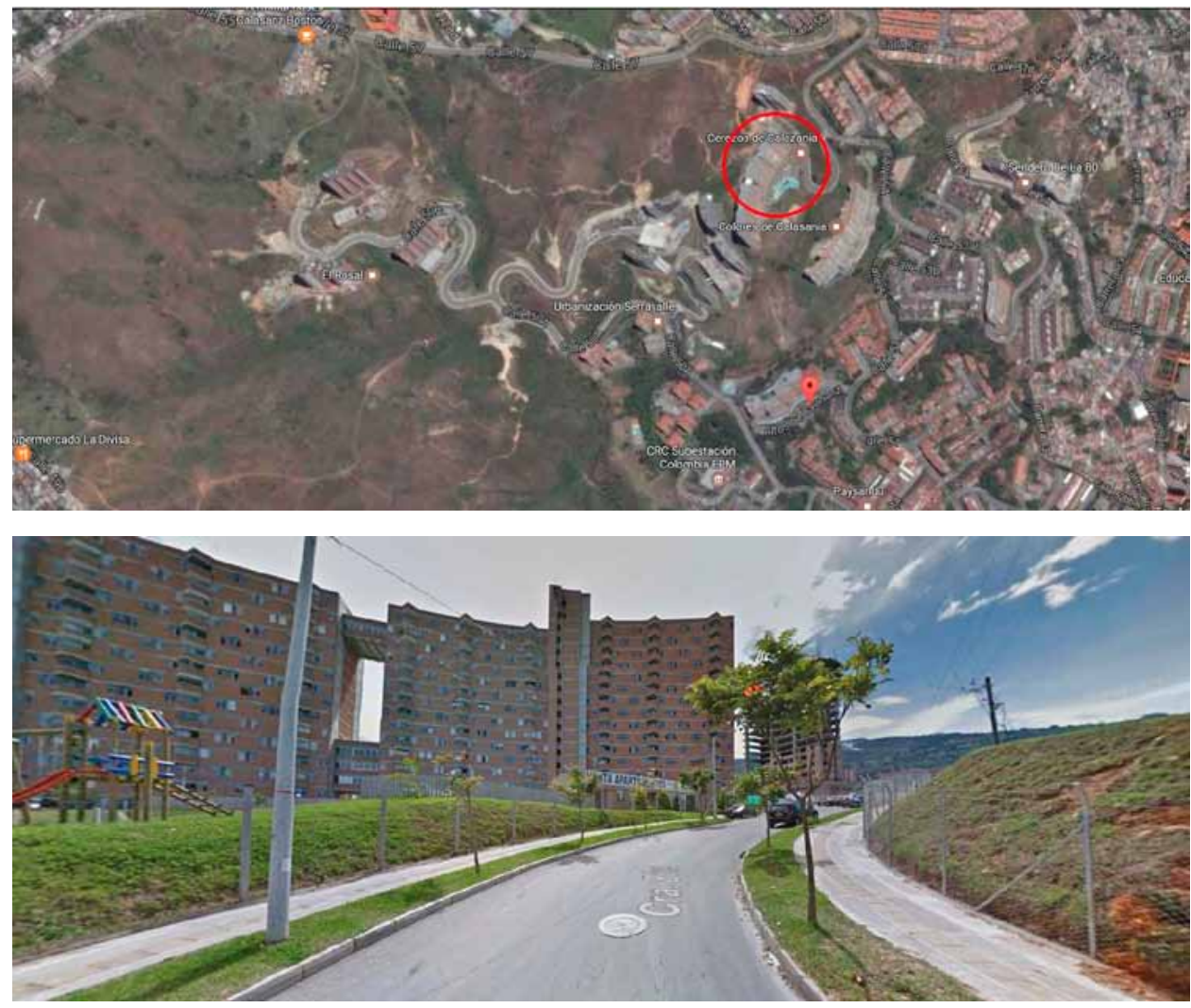

Fig. 14. Housing typology Plan Parcial Altos de Calasanz

Sources: Google Earth.

towards policies such as an appropriate mixed land uses). Recently, a new revision of the POT was made, by a group of young planners (Calderón 2012d). This revision envisages a revival of the 1999's approach in reaction to the negative effects of the functionalist approach such as monofunctional zonification.

The three urban planning paradigms of the 20th Century in Latin America identified by Jenkins et al. (2007), developed chronologically, but co-exist and overlap. Moreover, the timing of their application in Colombia does not perfectly correspond to their emergence and application elsewhere, demonstrating the rule of uneven development (Smith 1990): a society, a system, or a discipline, do not transform comprehensively throughout all sectors and territories at once. Rather, some areas - whether sectorial or spatial - may transform earlier and faster, while others lag behind created a patchwork of diverse practices, ideas, and conditions which all coincide at a specific moment. Such uneven development within Colombia is a possible explanation of the discrepancies between intentions and practice regarding the POT as well as of the diversity of opinions among local planners regarding the Functional City. I argue that the prevalence of the functionalist urbanism despite the mentioned shifts between urban planning paradigms is supported by a rhetoric planning that does not correspond in practice. In other words, Medellín's urbanism is and has been based on a "productive urban paradigm" subject to connection between political imperatives and market forces. Under this "productive urban paradigm", plans become mostly economic programs which respond to maximising private developer profit (land speculation) without comprehensive social programmes. In this way, urban functions are segregated through mass (social) housing production and large development of road infrastructure for instance (see Figs 7, 14 and 15b). However, as shown in Table 7, in general, the work function (limited mixture of functions) is presented strongly in Planes Parciales, located within medium to high socioeconomic areas.

During the interviews with some local key participants (i.e. planners), discrepancies about Functional City principles influence in the current urban development of Medellín were found (Calderon 2012a, 2012b, 2012c, 2013a). These discrepancies are based mainly on the shift between the physical urban planning approaches (master planning paradigm) to development planning (systems planning paradigm). There is a general consensus of the recognisable influence of Functional City principles in the urban development of Medellin before the 1980s but some scepticism 

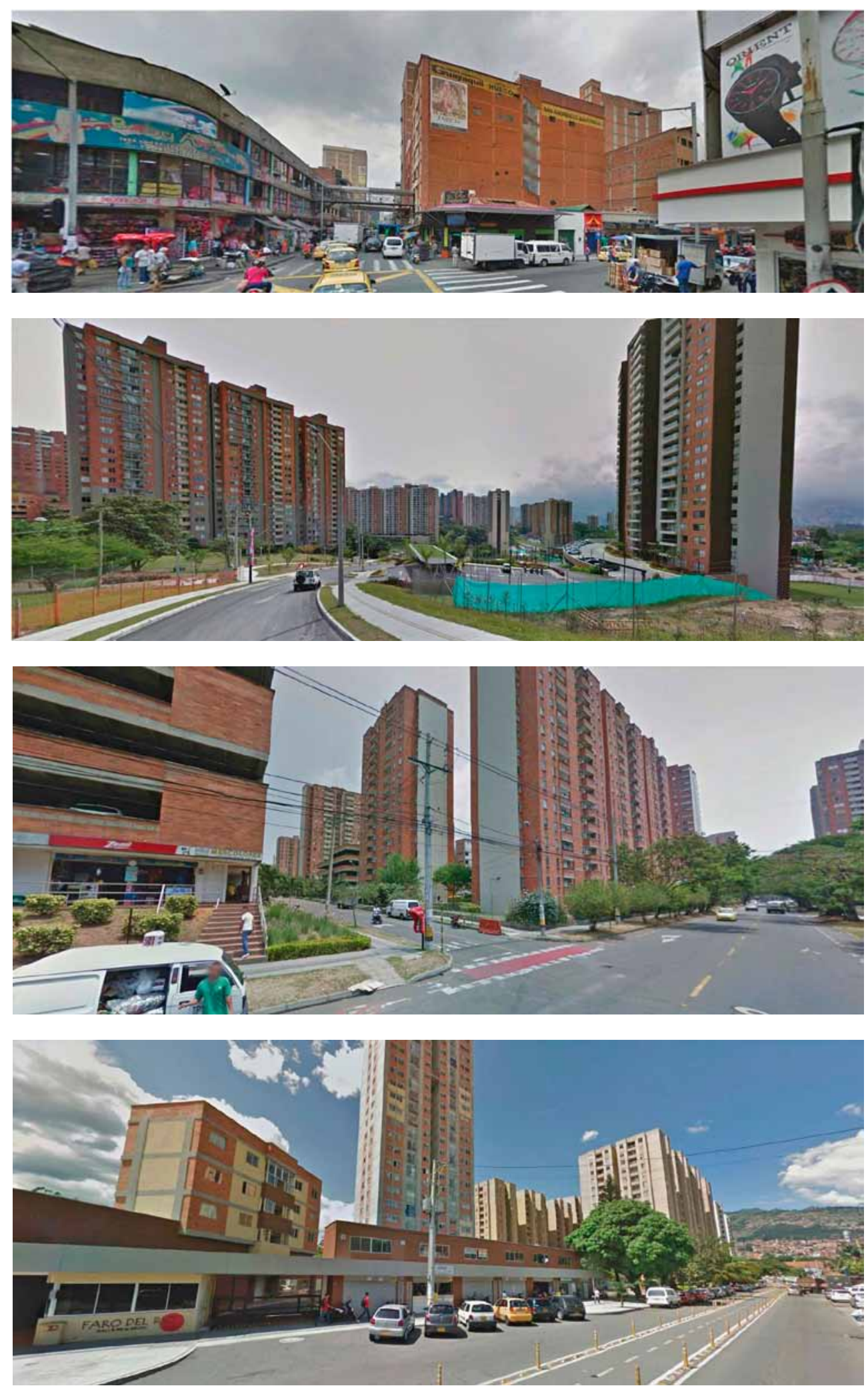

Fig. 15. Planes Parciales completed to date according to the Medellín's Planning Office. All of these plans show the predominant separation of urban functions in Medellín's urbanism. Up to down: 15a - Plan Parcial Guayaquil Manzana (commercial use), 15b - Plan Parcial Loma de los Bernal (predominant Housing use), 15c - Plan Parcial Parque Los Colores (predominant housing use) and $15 \mathrm{~d}$ - Plan Parcial Paseo Sevilla (predominant housing use).

Source: Google earth images. Accessed May 2017. 


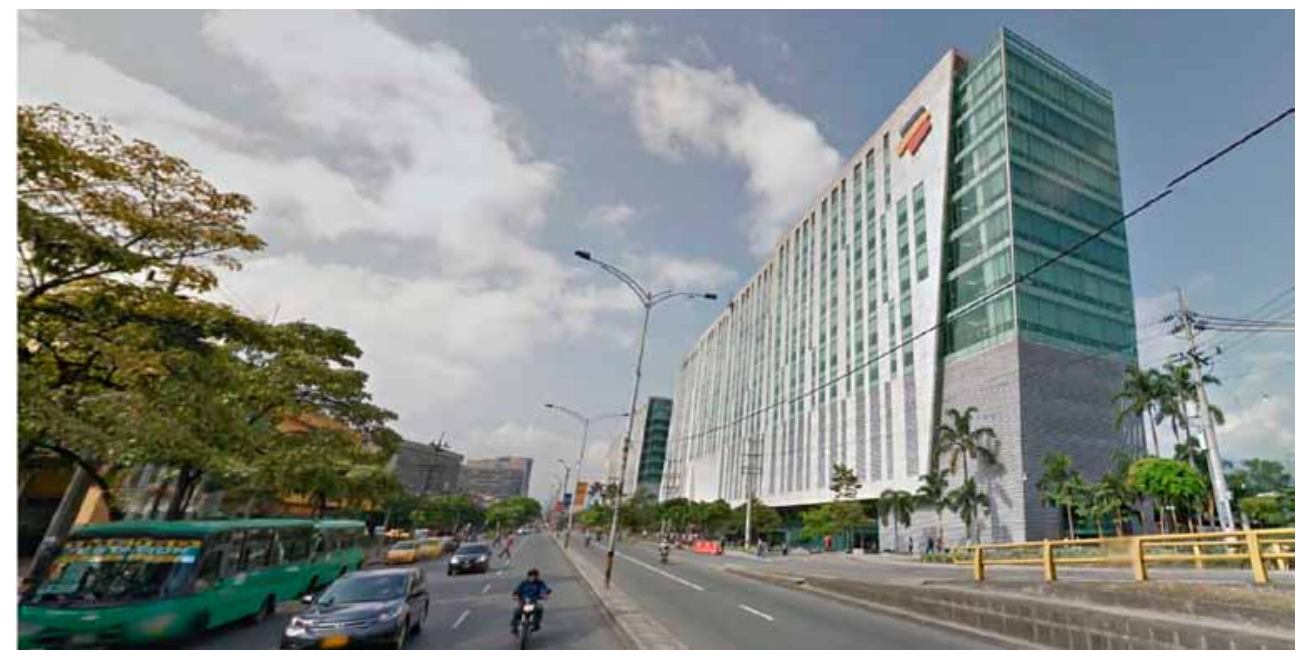

Fig. 16. Bancolombia headquarters in Medellín. This is the largest commercial bank in Colombia. Photo Google Earth, November 2016.

thereafter. Continuing with the elaboration of the uneven development demonstration in Medellín, this scepticism has a plausible explanation since in 1985 the Metropolitan Development Plan for Medellín and its metropolitan area (region) was delivered. This marked a "new" planning programme based on a multidisciplinary innovative (within Colombian context) approach influenced by the English Structure Plans introduced in 1968 which aimed a response to global market forces. More recently, it is believed that current application of Functional City principles in Medellín corresponds to a current worldwide trend (market conditions), and not to a plan for Medellín by CIAM (i.e. high-rise buildings as a response to governmental agendas for housing shortages and work function has undergone a mutation from industrial zones to massive service-based business buildings, Fig. 16).

Moreover, it is important to mention that the Functional City principles have been adjusted, modified or evolved according to local socio-economic, cultural and political circumstances. All of these factors respond to global trends such as the Political Constitution of 1991 and its guidelines towards to the internationalisation of the economy and its orientation aiming the market economy and competitiveness. Presumably, this "metamorphosis" of the Functional City principles have promoted such a discrepancy.

"The mere acceptance of functionalism guarantees nothing", De Zurko wrote. "It provides principles of convincing validity but not ready-made solutions" (De Zurko 1957: 240). Modernist urban planning served to solve quantitative and economic problems for the city, without addressing cultural identity and socio-economic conditions of the population (Frampton 1980: 297). CIAM principles in Medellín concentrated on making human activity "functional" but socio-eco- nomic, cultural and environmental aspects have been ignored.

Moreover, urban planning in Medellín requires less rationalisation and more flexibility and adaptability. CIAM's ambition to organise cities "rationally", is excessively opposed to Medellín's informal urban development and character. As the urbanism historian Christine Boyer states:

The entire urban context that configures architecture must be drawn into critical awareness: the regulatory controls, the political and economic conditions, the technical and social means of production, the cultural milieu. To reinterpret the spatial and historical elements of the city in this manner decodes the very meaning of the verb "to plan" (Boyer 1983: 287).

Indeed, the mishandled adoption of Functional City principles has contributed to the significant deterioration of the historical city centre of Medellín (Fig. 17). The centre was converted into a mono-functional (commercial) zone, which suggests that urban land use policy makers should be more aware of the socio-economic and cultural realities of the city, in order to achieve a more appropriate city zoning. Moreover, the arbitrary importation of foreign urban planning "formulas" such as the use of abstract demographic statistics in CIAM's Master Plan for Medellin, suggests lack of awareness of local circumstances of Colombian cities. For instance, massive forced displacement of people by violence made the Functional City approach for Medellín inadequate since it is very difficult to determine figures in terms of force-displaced population. In this scenario, it seems that the rigidity in which the Functional City has been conceived, is incompatible with local demands. Therefore, this raises the question 


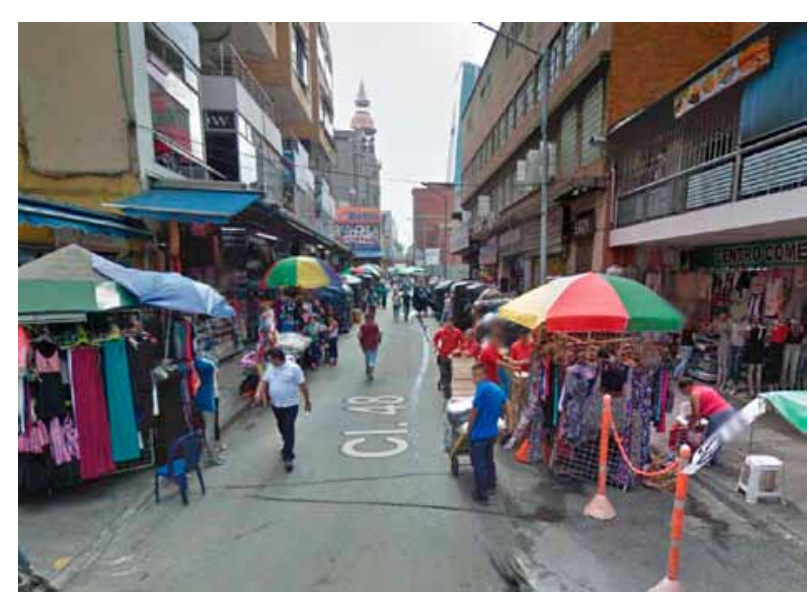

Fig. 17. Current conditions of Medellín's city centre. Photo Google Earth.

whether the Functional City is an attempt to standardise urban life, and how this approach can be adjusted to the complex and diverse scenarios that cities face today in Latin America?

After 60 years of implementing Functional City principles it is important to pursue further investigation and evaluation of the implications of these principles to the current environmental degradation of Medellín (i.e. chaotic urban expansion, mass low quality social housing production, lengthy commutes and heavy car usage). Indeed, in terms of chaotic urban expansion, the environmental degradation of Medellín has reached critical points with the proliferation of high-rise housing developments contributing to high densities, also in geologically and topographically challenging zones. These housing developments are not only reducing and deteriorating the Aburra's Valley landscape, but they are also putting human lives at risk, such as the avalanche that occurred in November 2008 in El Poblado, or the collapsing of the Space residential building in October 2013.

Another implication, is the environmental legislation regarding the relocation of heavy industry outside of the urban perimeter, which is creating lengthy commutes. The moving of industry outside the urban perimeter encourages problematic for-profit redevelopment and land speculation. Due to the advantageous central location of industry in Medellín, the freed land for housing developments is expensive and unaffordable for the low-income population (see the case study of Plan Parcial SIMESA). In summary, these are just two examples of the environmental implications of distorted Functional City principles applied in Medellín. Both are intrinsically related to economic planning that favours particular interests such as urban developers and stakeholders.

\section{Conclusions}

The three case studies (Planes Parciales), reveal some evidence to suggest that the Functional City principles still provide the ground of urban planning in Medellín since planners are inclined to favour it. Therefore CIAM's ideas for Medellín are still to some extent embedded in the urban development of the city.

Furthermore, this study also suggest that the acceptance and implementation of the Functional City principles in the 1950s, 1960s and 1970s in Medellín has meant that concepts of rational efficiency, standardisation, fragmentation (zoning), monotony, and historical disruption of tradition, have also been applied in the urban planning of the city since then. Considering the Master Plan (Plan Piloto) of Wiener and Sert as the first comprehensive urban planning approach for the city, confirms the strong roots that the Functional City planted in Medellín. This approach established a generally dominant modernist doctrine among local planners who accepted it and strongly resist to change it despite shifts in urban planning paradigms. For instance, zoning has been used in Medellín as a resistance to new global economic paradigms; in the last revision of the POT (2006) the plan promoted the protection of the industrial zones as mono-functional areas, although, the local economy of Medellín has been transformed into a service-based economy. This showed unawareness of the macro-economy (global market) in which Medellín is placed. However, in consideration of the inadequacy of plans that do not match the local reality, findings reveal the current willingness of local planning authorities to break the dominant functionalism of the urban planning of Medellín (Calderón 2012d) (e.g. rigid zoning).

\section{Acknowledgements}

The author would like to show his gratitude to Dr. Tahl Kaminer for his continuous support and engagement during the development of this manuscript. Many thanks for his comments and advice that greatly improved the manuscript. Also, many thanks to the interviewed key informants in the city of Medellin.

\section{References}

Alcaldía de Medellín. 2003. Plan parcial de renovación y consolidación en suelo urbano "Parque San Lorenzo". Documento Técnico de Suporte, Medellín [online] [cited 18 November 2016]. Available from Internet: https://www.medellin.gov. co/irj/go/km/docs/wpccontent/Sites/Subportal\%20del\%20 Ciudadano/Planeaci\%C3\%B3n\%20Municipal/Secciones/ Informaci\%C3\%B3n\%20General/Documentos/POT/ DOCUMENTO\%20TECNICO\%20DE\%20SOPORTE\%20 PLAN\%20PARCIAL\%20PARQUE\%20SAN\%20LORENZO.pdf

Alcaldía de Medellín. 2006. Plan de Ordenamiento Territorial. Acuerdo 46 de 2006 'por el cual se revisa y ajusta el plan de 
ordenamiento territorial para el municipio de Medellín y se dictan otras disposiciones'. Medellín.

Alcaldía de Medellín. 2011. Medellín: una ciudad q se piensa y se transforma. Departamento Administrativo de Planeación 50 años: 1960-2010.

Barnett, J. 2011. City design: modernist, traditional, green, and systems perspectives. Abingdon, Oxon; New York, NY, Routledge.

Boyer, M. C. 1983. Dreaming the rational city: the myth of American city planning. Cambridge: Mass. Mit.

Calderon, E. 2012a. "Interview with Alejandro Echeverry", Medellín, Centro de Estudios Urbanos y Ambientales (URBAM), Universidad EAFIT, December, 2012.

Calderon, E. 2012b. "Interview with Professor Emilio Cera", Universidad Nacional de Colombia, Sede Medellín. December, 2012.

Calderon, E. 2012c. "Interview with Dr. Patricia Schnitter", Professor and researcher Universidad Pontificia Bolivariana. Medellín. December, 2012.

Calderon, E. 2012d. "Interview with Juan Carlos Garcia”, consultant of POT for Medellín. December 2012, Medellín, Colombia.

Calderón, E. 2013a. "Interview with Professor Jorge Orlando Melo”, La Ceja, Antioquia, Colombia, January, 2013.

Calderón, E. 2013b. “Interview with Zoraida Gaviria”, Medellín, Escuela de Ingeniería de Antioquia, 5 April 2013.

Coninsa Ramón H.; Londoño Gómez; Arquitectura y Concreto. 2006. Plan Parcial Gran Manzana SIMESA. Documento Tecnico de Soporte [online], [cited 18 November 2016]. Available from Internet: http://www.medellin.gov.co/ $\mathrm{irj} / \mathrm{go} / \mathrm{km} /$ docs/wpccontent/Sites/Subportal $\% 20 \mathrm{del} \% 20$ Ciudadano/Planeaci\%C3\%B3n\%20Municipal/Secciones/ Informaci\%C3\%B3n\%20General/Documentos/POT/ DOCUMENTO\%20TECNICO\%20PLAN\%20PARCIAL\%20 GRAN\%20MANZANA\%20SIMESA.pdf

De Zurko, E. 1957. Origins of functionalist theory. New York: Columbia University Press.

Exaedro. 2007. Plan Parcial de Desarrollo En Suelo de Expansión "Altos de Calasanz". Documento Técnico de Soporte [online], [cited 18 November 2016]. Available from Internet: https:// www.medellin.gov.co/irj/go/ km/docs/wpccontent/Sites/ Subportal\%20del\%20Ciudadano/Planeaci\%C3\%B3n\%20 Municipal/Secciones/Informaci\%C3\%B3n\%20General/ Documentos/POT/DOCUMENTO\%20TECNICO\%20 PLAN\%20PARCIAL\%20ALTOS\%20DE\%20CALASANZ.pdf

Frampton, K. 1980. Modern architecture: a critical history. London, Thames and Hudson.

Guillen, M. 1997. Scientific management's lost aesthetic: architecture, organisation, and the taylorized beauty of the mechanical, Administrative Science Quarterly 42(4): 682-715. https://doi.org/10.2307/2393654

Jenkins, P.; Smith, H.; Wang, Y. P. 2007. Planning and housing in the rapidly urbanising world. Housing, planning, and design series. London: Routledge.

Le Corbusier. 1973. The Athens charter. New York, USA: Grossman.

Le Corbusier; Etchells, F. 1971. The city of tomorrow and its planning. 3rd ed. London: Architectural Press.

Mumford, E. P. 2000. The CIAM discourse on urbanism, 19281960. Cambridge: Mass; London: MIT Press.

Mumford, E.; Sarkis, H.; Bacon, M.; et al. 2008. Josep Lluís Sert: the architect of urban design, 1953-1969. New Haven; Cambridge: Yale University Press; Harvard University Graduate School of Design.
Mumford, E. P. 2009. Defining urban design: CIAM architects and the formation of a discipline, 1937-1969. New Haven: Conn.; London: Yale University Press.

Congreso de la República de Colombia. 1947. Ley 88 del 15 de Diciembre de 1947. Sobre fomento del desarrollo urbano del municipio y se dictan otras disposiciones.

Congreso de la República de Colombia. 1989. Ley 9 del 1 de Enero de 1989. Ley de Reforma Urbana.

Congreso de la República de Colombia. 1997. Ley 388 de 18 de julio de 1997. Ley de Desarrollo Territorial.

Restrepo Ruiz, A. 2011. Poder y gestión del suelo. Estudio de planes parciales en la ciudad de Medellín: Master's thesis. Escuela de planeación urbano-regional, Facultad de Arquitectura, Universidad Nacional de Colombia, Sede Medellín.

Rovira, J. 2003. José Luis Sert, 1901-1983. Milan, Electaarchitecture.

Schnitter, P.; Patino, J. M.; Salazar, S., et al. 2007. Estudio de la forma y el crecimiento urbano de la Región Metropolitana. Fase 1: Mapificación del crecimiento urbano del Valle de Aburrá. Area Metropolitana del Valle de Aburrá and Universidad Pontificia Bolivariana [online], [cited 4 June 2012]. Available from Internet: http://www.areadigital.gov.co/institucional/ Documents/Estudio_de_la_Forma_fase_1.pdf

Sert, J. L.; International Congresses for Modern Architecture. 1947. Can our cities survive? An ABC of urban problems, their analysis, their solutions; based on the proposals formulated by the C.I.A.M., International congresses for modern architecture, Congrès Internationaux d'Architecture Moderne. Cambridge: Mass.; London: Harvard University Press; Geoffrey Cumberlege: Oxford University Press.

Smith, N. 1990. [1984] Uneven development: nature, capital and the production of space. Athens, Georgia: University of Georgia Press.

Smithson, A.; Architectural Association. Graduate School. 1982. The emergence of team 10 out of C.I.A.M: documents. AAGS theory and history papers. London, Architectural Association.

Somer, K. 2007. The functional city: the CIAM and Cornelis van Eesteren, 1928-1960. Rotterdam; The Hague, NAi Publishers; EFL Foundation.

Somol, R. E. 1997. Autonomy and ideology: positioning an avant-garde in America. New York: The Monacelli Press.

\section{EDWAR CALDERÓN}

is a Postdoctoral Research Assistant at the School of Geosciences at the University of Edinburgh. He attained his $\mathrm{PhD}$ in urban studies at the Edinburgh School of Architecture and Landscape Architecture (ESALA) where he was a Studio tutor from 2011 to 2015. He holds a Masters degree in Landscape Architecture and a certificate in Historic Preservation and Regionalism both from the University of New Mexico, USA, where he worked as a research assistant, participating in several community development projects and as a teaching assistant. Edwar is a chartered architect from Colombia and member of the Sociedad Colombiana de Arquitectos - SCA - (Colombian Architects' Society). Edwar's research interests lie in urban practices towards more sustainable and equitable human settlements in Latin America. His current research explores theories of spatial justice to understand the processes shaping the contemporary development and rapid transformation of land use in the Pacific Region of Colombia and how these processes deepen and extend inequality and injustice in the city. 